\title{
A literatura moçambicana: caminhos da consolidação
}

\author{
Pedro Napido \\ Faculdade de Letras e Humanidades, \\ Universidade Licungo, Moçambique
}

DOI: https://doi.org/10.31492/2184-2043.RILP2020.37/pp.73-91

\begin{abstract}
Resumo
O presente artigo é uma parte da tese de doutorado sobre a história da emergência da literatura infantil e juvenil em Moçambique através dos autores, obras e das fontes. O mesmo tem por objetivo demonstrar o percurso da literatura moçambicana e os caminhos da consolidação assim como sua contribuição na construção da identidade e da nacionalidade. A leitura do arcabouço teórico de partida, desenvolvido por Candido (1999), Leite (2008), Mendonça (2011), Matusse (2015) e Noa (2008) permitiu compararmos a realidade literária no Brasil em relação a de Moçambique e concluímos que neste último, enquanto país jovem e em construção, a literatura caminha para a sua consolidação, enquanto sistema.
\end{abstract}

Palavras-chave: consolidação; identidade; literatura; Moçambique; nacionalidade.

\section{Abstract}

This article is part of the doctoral thesis on the history of the emergence of children's and youth literature in Mozambique through authors, works and sources and aims to demonstrate the path of Mozambican literature and the paths of consolidation as well as its contribution to construction of identity and nationality. Reading the theoretical framework of departure, developed by Candido (1999), Leite (2008), Mendonça (2011), Matusse (2015) and Noa (2008) allowed us to compare the literary reality in Brazil with that of Mozambique and we conclude that in this finally, as a young and under construction country, literature is moving towards its consolidation as a system.

Keywords: consolidation; identity; literature; Mozambique; nationality.

\section{Introdução}

A cultura moçambicana pode ser entendida num quadro que remonta a partir da origem da própria sociedade por volta dos anos 200 ou 300 a.C. Em seguida, depois da fixação dos povos bantu não só houve contatos comerciais com os povos do Oriente para a troca do ouro e marfim por tecidos, miçangas, porcelanas e outras quinquilharias como também nas influências culturais e artísticas. Muitas vezes, para assegurarem os seus negócios os visitantes formavam famílias com as filhas dos chefes locais. Estas relações conjugais eram mais notórias na zona costeira onde se formaram pequenas feitorias que mais tarde viriam a ser invadidas e os mercadores expulsos pelos portugueses atraídos pelo ouro, de 1505 a 1692, marfim, de 1693 a 1750 e finalmente pelo tráfico de escravos, de 1750 a 1860.

Para entendermos a história da emergência da literatura moçambicana, olhemos para o caso brasileiro, tal como Candido (1999, pp. 14-5) defende: 
O sistema literário é uma articulação de elementos que constituem a atividade literária: autores formando um conjunto virtual e veículos que permitem o seu relacionamento, definindo uma «vida literária»; o público, restrito ou amplo, capaz de ler ou ouvir as obras, permitindo com isso que elas circulem e atuem; tradição, que é o reconhecimento de obras e autores precedentes No caso brasileiro, o sistema literário distingue 3 etapas: (i) a era das manifestações literárias; (ii) a era de configuração do sistema literário e (iii) a era do sistema literário consolidado.

Com base nestes pressupostos podemos afirmar que em Moçambique temos autores entre adultos e jovens que produzem obras num ritmo acelerado com temática diversificada, obedecendo a tradição literária e um público leitor que tende a ser cada vez mais amplo, devido à massificação do ensino no período pós-independência.

Neste caso, a literatura moçambicana teve as suas manifestações e simultaneamente a sua configuração nos finais do século XVIII até ao século XX graças aos seguintes acontecimentos: a fundação das primeiras escolas; introdução da tipografia em 1854 data em que se inicia a publicação de Boletim Oficial; o surgimento do primeiro periódico, O Progresso em 1868; a formação das zonas urbanas e suburbanas; as mudanças socioeconômicas na colônia e a formação das elites letradas inconformadas com a sua condição assim como o surgimento do jornalismo.

Por conseguinte, parece que só com o surgimento da Nação, no dia 25 de junho de 1975 é que a literatura moçambicana inicia a caminhada para a sua consolidação enquanto sistema.

\section{Caminhos da consolidação}

Em 1985 Manuel Ferreira compila um total de 31 poemas numa obra intitulada $O$ Mancebo e Trovador Campos de Oliveira, do primeiro poeta moçambicano, José Pedro da Silva Campos de Oliveira (1847-1911), nascido na Cabaceira, uma das localidades da Ilha de Moçambique, de pai goês e mãe moçambicana; fez a educação primária e secundária em Goa onde morou até 1867. Frequentou o curso de Direito na Universidade de Coimbra, Portugal. Depois da formação, na Ilha, como funcionário público, ocupou vários cargos, entre os quais de diretor dos Correios.

Williams (2005, p. 64) alerta para o fato de: "Até nova pesquisa provar em contrário, José Pedro da Silva Campos Oliveira tem a distinção de ser o primeiro poeta moçambicano de expressão portuguesa e o único que se conheça do século XIX".

A poesia de Campos Oliveira carateriza-se pela influência dos poetas portugueses, obviamente, da qual a imagística romântica ressurge no amor medieval 
e a trovadoresca dos antigos cancioneiros percorre a sua temática. É nessa ótica que, caracterizando a poesia insular em Moçambique, desde as primeiras manifestações até aos nossos dias, Secco (1999, p. 14) afirma: "O oceano revela como local de pesca, da faina cotidiana e de sobrevivência".

O alinhamento temático com a realidade europeia da época da qual Campos Oliveira é tributário deve ser entendido tendo em vista a natureza do contexto educacional e vivencial da época, aliada aos destinatários da sua mensagem literária. Entretanto, na passagem a seguir, a visão crítica de Noa (2008, p. 36), segundo a qual, "Campos Oliveira traduz já na sua escrita alguma preocupação temática com Moçambique, embora pouco significativa e pouco consequente, tendo em vista o conjunto daquilo que viria a ser a literatura moçambicana", parece divergir, de certa forma, com Leite (2008, p. 62) ao corroborar com Secco (1999, p.14) ora citado: "O poeta tem em conta a importância da Ilha e do Índico, enquanto referência temática fundamental na produção poética moçambicana do século seguinte".

Uma das caraterísticas da literatura moçambicana é o fato de não ter apenas orientação temática com base na realidade continental mas também insular uma vez que no litoral se regista maior diversidade cultural devido ao contato com vários povos, em trocas comerciais, principalmente com os asiáticos e os da África Oriental.

\section{Literatura colonial como justificativa da ação ideológica}

A colonização portuguesa em Moçambique caracterizou-se pela subversão das atmosferas sociais vigentes ainda que à sua chegada houvesse pequenos conflitos entre os estados Shona devido ao controle da extração e comercialização dos recursos naturais, principalmente ouro. Newitt (1995, p. 37) afirma: "Em 1513, a ocupação portuguesa na costa aumenta porque os mesmos abandonaram a sua feitoria de Quíloa e a sua atividade no Índico foi crescentemente marcada pela imposição do monopólio e do controlo político".

Esta ocupação era feita com ajuda dos soldados de expedições marinhas armados de espadas, canhões, lanças usando embarcações sofisticadas, comandadas por capitães ao serviço do rei ou de um dos príncipes em busca de fortuna, fama e recompensa.

A partir da zona costeira, os portugueses iam fazendo suas incursões para o interior aniquilando ou intimidando os seus opositores pela força das armas e, ao mesmo tempo, pacificando o nativo com ajuda dos missionários através da ação batismal dos reis. Desta forma, conseguiram controlar os circuitos comerciais, dominando os estados e aos poucos implantando a sua hegemonia até à ocupação efetiva, depois da partilha de África efetuada na Conferência de Berlim, em 1895. 
Sobre a presença colonial portuguesa em Moçambique Sousa (2014, p. 18) afirma: "Para além da representação militar, geográfica, política e econômica também se fez através da escrita de textos biográficos e autobiográficos, tratados políticos, diários, relatórios de missionários, cartas, memórias, romances enquanto garantias de sobrevivência do império".

Portanto, importa salientar que essas ideologias foram repelidas de diversas formas pelo nativo desde à primeira hora. Como resposta aos mecanismos de revolta do nativo resultado da invasão da terra e implantação da máquina colonial, mais uma vez, Sousa (2014, p. 13) enfatiza: “Ao longo dos séculos, o Estado português recorreu a diferentes formas de representação e construção do seu Império em África. Uma dessas estratégias de interpretação, valorização, afirmação e justificação do Império foi através da literatura colonial". Podemos observar que esta estratégia visa contrapor-se à da perspectiva africana que era anticolonial.

Deste modo, a literatura colonial atravessou várias etapas justificadas pela dinâmica da própria colonização e grande parte das obras são de caráter autobiográfico e diarístico com a temática de viagem em que os personagens são revestidos de coragem de modo a transporem perigos para o desenvolvimento colonial.

Noa (1999, pp. 63-5) divide a literatura colonial em 3 fases: “(i) fase exótica; (ii) fase ideológica e (iii) fase cosmopolita".

As fases da literatura aqui apresentadas nos remetem para o fato de a primeira revelar os efeitos de um contato com o desconhecido em que os objetivos do europeu e do nativo eram totalmente diferentes. Como exemplo desse período, Sousa (2014, p. 106) considera na paráfrase da obra Céus de Fogo (1933), de Campos Monteiro Filho, vencedor do primeiro prêmio da segunda categoria do concurso da literatura colonial, em 1933, de cunho autobiográfico, o narrador tenta descrever os hábitos, as tradições e mentalidades indígenas. Contrariamente ao europeu que tinha a finalidade de dominação e exploração, a visão inocente do nativo considerava-o como um viajante ou hóspede e como tal deveria ser tratado segundo os hábitos e costumes locais.

Da leitura tanto de Sousa (2014) quanto de Noa (1999) entendemos que em Moçambique, a segunda fase da literatura colonial investe mais em estereótipos que explicam a exclusão socioeconômica não só pela tentativa de apagamento da cultura e línguas indígenas consideradas selvagens, primitivas e não evoluídas em relação à realidade ocidental mas também tratando o nativo como Outro.

Tal como acontece em outras manifestações do sistema colonial português, o que de comum notamos, em todas as obras do período, é a existência explícita de uma supremacia da raça com o objetivo civilizatório. Evidentemente, desencadeia-se a visão comum do português em relação à África, nomeadamente, a 
superioridade civilizacional e moral do europeu em relação ao africano, o medo das febres, a imagem do ambiente africano como degradante, o tédio, a saudade de Lisboa, o africano como bêbado, selvagem, ingênuo, ladrão e portador de sarna, piolhos, sarampo, cólera e de todo o tipo de doenças contagiosas cujo contato físico com o branco devia ser evitado a todo o custo.

A terceira fase da literatura colonial, a partir dos princípios da década de 1960, regista um abrandamento das tensões estereotipadas do europeu em relação ao africano graças ao contexto histórico e à pressão internacional sobre a política desumanizante colonial portuguesa sobre o negro. Assim, perante esse clima, Portugal procura justificar-se sobre as razões da perpetuação da sua presença em África, cultural e historicamente.

A literatura colonial tem suscitado vários posicionamentos entre os estudiosos, como Chaves (2003, p. 211) ao afirmar: "Num quadro assim, a atividade literária despe-se da sua função humanizadora e incorpora o papel de partícipe num processo ideológico nitidamente associado à dominação" e Noa (1999, p. 59), por seu turno, sobre a complexidade do estudo desta literatura na atualidade, considera: "O termo colonial desperta alguns fantasmas que têm a ver com sentimento de culpa, ressentimentos e mágoas ainda latentes". Leite (Leite 2013, p.229). , por sua vez, fazendo a revisão do arquivo da literatura colonial portuguesa na narrativa moçambicana, nos romances Choriro (2009), de Ungulani Ba Ka Khosa e Outro pé da sereia (2006), de Mia Couto, considera esses romances importantes no panorama histórico literário moçambicano:

\footnotetext{
Se a história não permite, na maioria das vezes, a abordagem das narrativas marginais, das vivências esquecidas e das emoções que com elas foram experienciadas, a literatura pode, enquanto discurso sobre a nação, ser campo para a invenção de diversas formas de narratividade, em que a pesquisa histórica repõe acontecimentos e eventos singulares, envolvidos no desconhecimento, provocados pelo esquecimento e pela erosão da memória. Torna-se, então, produtivo constatarmos como o romance configura simbolicamente os eventos e sentidos desagregadores, provocados ou por silenciamento histórico, ou por desejo de esquecimento ou, ainda, por ausência de memória.
}

Essa literatura sinaliza a insustentabilidade e ineficácia do império colonial português e como saída era necessário adocicar os fatos para escamotear a realidade. Para isso, apesar da sua "função desumanizadora" e "despertar alguns fantasmas" faz parte da literatura moçambicana e deve ser lida e conhecida. De uma forma geral, a literatura colonial foi uma das estratégias usadas pelo colonizador para se impor em África desvirtuando a realidade do nativo e sua cultura durante séculos e, por seu turno, de uma forma particular, o africano usou a língua portuguesa como uma das formas de resistência e de sobrevivência, expressando a 
literatura como um dos meios de sua libertação do jugo colonial e na negociação da identidade cultural flagelada.

\section{Literatura moçambicana antes da independência}

No século XX registaram-se mudanças sociais, políticas e econômicas significativas que favoreceram a tomada de consciência ao nativo da sua condição de colonizado. Isso surgiu na sequência da existência de jornalistas, acadêmicos, assimilados, mulatos, brancos moçambicanos e uma pequena classe média urbana e suburbana que se opunha ao sistema implantado. Com esse panorama, a atividade jornalística foi uma das promotoras da produção e circulação de textos literários. Caracterizando essa geração, Leite (2013, p. 23) afirma:

Que uma parte significativa dos escritores são assimilados e de descendência europeia, sem contato direto com o campo e, com algumas exceções, nem todos dominam as línguas africanas, frutos da política colonial que separava os africanos de civilizados/não civilizados, sendo a língua e cultura indígenas tidas como não civilizadas/selvagens.

É nesse quadro que se afigura a literatura moçambicana, em sua primeira fase, como observa Mendonça (2011, p. 12), está marcada pela atividade jornalística e literária, veiculada notadamente pelos jornais $O$ Africano (1908-1918) e O Brado Africano (1918 - 1974), nas décadas de 1920 e 1930, e pela poesia de Rui de Noronha, cuja expectativa oscilava entre ser africano e ser europeu. Esta fase é marcada pelo surgimento da primeira obra literária, O Livro da dor (1925), de João Albasini, numa edição póstuma.

No mesmo período, a atividade literária e jornalística é praticada ainda pelos irmãos João e José Albasini, Estácio Dias, Karel Pott, Rui de Noronha, Nicamor da Silva, Guidione de Vasconcelos, Gastão e António da Silva. As críticas, por vezes acutilantes, cingiam-se na interpelação da máquina colonial.

A partir da década de 1940 foram operadas mudanças no sistema internacional, desfavoráveis à legitimidade dos impérios coloniais. Assim, Portugal vê cada vez mais a dependência das colônias sendo posta em causa, apesar da concepção assimilacionista, a partir da qual as colônias se transformavam em províncias ultramarinas, formando com a metrópole uma nação una. Contudo, essa medida não eliminou a descriminação racial, econômica e política com base nas leis desfavoráveis ao nativo, na identidade híbrida do assimilado, a exploração física e braçal do nativo.

É nesse panorama que em Moçambique irá produzir-se uma literatura voltada, em grande parte, para as questões africanas em geral, e moçambicanas em 
particular (ser africano v.s. ser europeu). Nesta fase, os poetas problematizam o ser europeu, a par do movimento da Negritude cultivado em outros contextos. Mendonça (2011, p. 12) afirma: "Há uma tendência utópica que se transforma progressivamente num conjunto de valores de grupo exibidos como contra discurso, criador de uma nova ordem, instituindo-se, por isso, em ideologia".

A exaltação do africano e das suas raízes profundas, numa poética vibrante e de forte impacto social, procura resgatar a face negra oprimida e racialmente envergonhada durante séculos. O Itinerário busca inclusive elementos e caraterísticas peculiares da vida indígena, como sejam o folclore, expresso em contos, lendas, adivinhas, provérbios, anedotas, práticas terapêuticas, culinárias, mágicas e agrícolas.

Na mesma época funda-se o jornal cultural Msaho (1952), por Virgílio de Lemos, Reinaldo Ferreira, Augusto Santos Abranches, Antero Machado, João Ayres, Domingos Azevedo e Eugénio de Lemos, que teve apenas um número.

À semelhança de $O$ Brado Africano e Itinerário, Msaho tinha não só objetivo literário como também projeto cultural e político, e nele vários poetas publicaram os seus textos. Além dos fundadores, colaboraram: Noémia de Sousa, Fonseca Amaral, Orlando Mendes, Rui Nogar e José Craveirinha.

Para além da poesia produzida nessa época foram publicados dois romances: Portagem (1960), de Orlando Mendes, considerado por Noa como sendo o primeiro romance moçambicano, que aborda a dominação, o racismo e a identidade do mulato em Moçambique; As raízes do Ódio (1963), de Guilherme de Melo, que problematiza as relações sociais entre europeus e africanos no contexto colonial. Destacam-se também duas coletâneas de contos, Godido e Outros Contos (1952), de João Dias, considerado iniciador da ficção narrativa moçambicana cuja temática oscila na exortação da não aceitação da ordem social montada pelo sistema colonial português e denuncia o clima ideológico da época e Nós Matámos o CãoTinhoso (1964), de Luís Bernardo Honwana, que, na mesma estética vigente, denuncia a humilhação e opressão com base na hierarquia racial e na relação patriarcal entre o europeu e o africano, apelando para a tomada de consciência, resistência e revolta do nativo.

O nacionalismo mantido pelos escritores moçambicanos nessa fase culminou com a fundação da FRELIMO em 1962, para o início da luta armada contra o colonialismo português e alargou a produção de textos literários aos combatentes. Essa produção literária é chamada "Poesia de Combate". Os escritores mais destacados são: Marcelino dos Santos, Sérgio Vieira, Armando Emílio Guebuza e Jorge Rebelo. 
Falar da literatura moçambicana antes e depois da independência, como veremos a seguir, é reconhecer o papel importante exercido pela oralidade como veículo da cultura e da necessidade de ser permanentemente estimulada. Ela preserva a tradição da experiência acumulada, renovando-se, a cada momento, na fixação transversal da história literária moçambicana, no passado, presente e futuro.

Por um lado, a literatura colonial serviu para fazer crer a conveniência do sistema colonial para os africanos porque tinha uma função civilizadora. Torna-se importante que a mesma seja conhecida e divulgada porque faz parte do património cultural de Portugal e de Moçambique. Do mesmo modo, foi escrita em e sobre Moçambique, numa língua partilhada entre vários povos. Por outro, o colonizado tinha uma visão negativa pelas injustiças perpetradas pelo sistema colonial usou também a literatura como uma das formas de resistência e sua libertação.

\section{Literatura moçambicana no período pós-independência}

$\mathrm{O}$ acesso à independência conferiu a Moçambique, tanto na vida cultural como econômica e política, novas e grandes possibilidades de desenvolvimento e progresso: multiplicaram-se as instituições culturais, escolas, a livre expressão da criatividade individual e coletiva, não reprimida pelas autoridades coloniais, uma ampla expressão da vida cultural e literária de matriz local e não só, a importância do fator político no desenvolvimento, na afirmação das artes e letras e uma vigorosa dignidade literária e artística.

As tendências variadas só viriam a ser concretizadas a partir dos meados da década de 1980, uma vez que o projeto da utopia de construção da nação, visando à mudança das mentalidades, teria como base as novas ideias difundidas principalmente através da cultura.

Durante a guerra de libertação nacional surgem dois "tipos" de escritores: uns na frente do combate e nas zonas libertadas, usando, ao mesmo tempo, a arma e a palavra como instrumentos de libertação. Esses autores produziram grande parte da poesia de combate; e outros que se encontravam nas zonas ocupadas pelo colonialismo, atuando na clandestinidade e usando apenas a palavra como meio de libertação colonial. Depois da independência e no processo de construção da nação, os dois "tipos" de escritores moçambicanos uniram-se para a mesma finalidade. Mendes (1980, p. 179) observa:

Os escritores moçambicanos encetaram os primeiros passos para se organizarem como força ao serviço da nova sociedade que estamos a construir. A escolha é clara e impõe-se porque o escritor moçambicano participa ativamente na reconstrução nacional e sabe que para todos os trabalhadores - e ele é-o 
também, usando como ferramenta a palavra - a comparticipação por direito próprio no património universal exige como condição básica a realização e consolidação no nosso espaço político, económico e, sobretudo, cultural, da verdadeira independência. Entendemos que a literatura tem o seu lugar, o seu papel e a sua função na frente cultural do combate contra a burguesia, contra o capitalismo e o imperialismo, pela dignificação do homem e da personalidade nacional, pela felicidade, pela justiça, pela solidariedade e pela Paz.

A passagem mostra claramente o comprometimento do escritor não só com o projeto político do governo moçambicano como também perante o povo e a revolução, tendo em vista a visão sociopolítica e cultural da época.

A conquista da independência não era só no âmbito político, socioeconômico como também cultural na qual a colonização teve maior impacto. Desse modo, no caso específico da literatura, a nacionalidade do escritor deveria desempenhar um papel fundamental no processo revolucionário, tal como Mendonça ( 2011, p. 17) explica:

\footnotetext{
Numa concepção bastante aproximada do realismo socialista jdanovista o escritor só era legitimado pelas práxis revolucionárias, elevando-se então à categoria de símbolo nacional, tal como a bandeira, o hino, a moeda, a forma de vestir ou o passaporte. Como consequência desta concepção, à ideia de autor nacional e por extensão a sua produção artística, passou a ser associada a de território nacional o que determinava a "condenação" ou retirada da cidadania literária aos escritores que, por várias razões por vezes pessoais, não residiam ou tinham deixado de residir no país.
}

Os escritores mais notáveis dessa época são: Rui Nogar, Orlando Mendes, José Craveirinha, Leite Vasconcelos, Eliodoro Batista, Albino Magaia e Luís Carlos Patraquim. Pela iniciativa do Estado dirigido pela FRELIMO, assistiu-se, nessa altura, a publicação de obras inéditas, por razões políticas. Portanto, eram publicadas as obras que estivessem em sintonia com a ideologia vigente e cumprissem o projeto de construção da Nação sonhada.

Em agosto de 1982 é fundada a Associação dos Escritores Moçambicanos (AEMO) cujos estatutos revelavam uma grande "dosagem" marxista-leninista, e alguns associados eram quadros e/ou fundadores da FRELIMO, como por exemplo: Marcelino dos Santos, Armando Emílio Guebuza, Júlio Carrilho, Sérgio Vieira e Fernando Ganhão. Em seguida, em 1984, no interior da Associação dos Escritores Moçambicanos (AEMO) surge a revista Charrua, liderada por jovens que viriam a imprimir uma nova dinâmica no panorama literário moçambicano. Os acesos debates resultantes da heterogeneidade entre os que mantinham uma "pureza ideológica marxista" e os "rebeldes" não se faziam apenas dentro da AEMO como também em artigos de opinião nas páginas do Suplemento de Artes e Letras do Semanário Tempo. 
A institucionalização literária a partir da AEMO e o nascimento da revista Charrua destacam-se pela qualidade de sua escrita e profunda liberdade estética, os seguintes escritores: Ungulani Ba Ka Khosa, Eduardo White, Armando Artur, Marcelo Panguana, Suleimane Cassamo e Helder Muteia.

Sobre esta geração de escritores da revista, Basto (2008, p. 78) considera:

\begin{abstract}
A revista Charrua (1984) e os seus poetas, iniciam a releitura da apresentação do "intimismo" como estratégia literária de subversão do modelo oficial (modelo revolucionário que definia a literatura através da ideia de uma adequação a um conteúdo político-ideológico), o conflito de gerações, a progressiva institucionalização literária e a reflexão sobre a questão identitária do escritor moçambicano, se destacam nesta década.
\end{abstract}

Outro acontecimento mais significativo que marcou a área da literatura foi a publicação da obra Vozes Anoitecidas (1986), de Mia Couto, sobre a qual Mendonça (2011, p. 19) comenta: "Dá origem a uma polémica com vários intervenientes por conter linguagem inventiva e simuladora da oralidade, quebrando, assim, o paradigma socialista". Grande parte dos contos dessa obra são atravessados por temas ligados ao impacto da guerra civil no tecido social moçambicano, o seu efeito desagregador da vida tradicional das comunidades rurais por ter sido o epicentro dos confrontos entre as duas forças em conflito, no que diz respeito à convivência caótica com os mortos, feridos e nomadismo pela procura constante de abrigos quer nas zonas urbanas quer em países vizinhos. Leite (2013, p. 31) observa: "A língua que Mia Couto utiliza nos contos de Vozes anoitecidas procura ser uma forma de mediatizar, harmonizar, a constante crise que a sociedade moçambicana vive através das histórias trágicas do seu quotidiano".

A partir da publicação da obra coutiana até aos nossos dias, tem se notabilizado vários escritores produzindo textos em vários gêneros literários com temas diversificados e a literatura cumprindo a sua função humanizadora. Desse modo, a literatura moçambicana vai atingindo um número considerável de escritores com liberdade criadora e obras produzidas pela nova geração de origem urbana e suburbana, de modo que a fronteira entre o centro e a periferia seja ténue, contemplando talentos que vão emergindo através dos concursos literários em diversas instituições e círculos acadêmicos.

\title{
5. Contribuição da literatura na construção da identidade e da nacionalidade
}

Para Moçambique, colônia portuguesa até 1974, migram elementos culturais como objetos mimetizados nos textos literários, reveladores da imposição da cultura ocidental durante vários séculos. A cultura e religião ocidental estão "encurraladas" e convivem com a realidade social díspar e multifacetada como é o 
caso da poligamia e a monogamia, a tradição e a modernidade, o monoteísmo e o politeísmo, a escrita e a oralidade, o centro e a periferia, a pobreza e a riqueza, o patriarcado e o matriarcado, o campo e a cidade, entre vários. É com base nesses aspetos que a literatura é marcada por tendências variadas e os escritores da nova geração se filiam a uma estética não só nacional ou regional, mas mantêm um vínculo com a realidade universal.

Essas considerações nos induzem à crença da representação do mundo social medir-se pela sua credibilidade, aceitação e capacidade mobilizadora e não necessariamente pela sua veracidade. Para entendermos melhor a política da identidade enquanto relação de poder, no período colonial, é preciso citarmos Cabaço (2009, p. 20)

\footnotetext{
A política de identidade promovida pelo colonialismo tinha o objetivo de legitimar sua dominação e, no caso da última vertente luso tropicalista, de incentivar a criação de uma sociedade civil à qual se opôs a natureza tendencialmente dual e antagónica do sistema. Essa ação, que desconstruiu aspetos importantes da organização do poder tradicional, estimulou respostas culturais que reforçaram identidades de resistência pela apropriação de subsídios da "modernidade" do colonialismo no próprio património de conhecimentos e de vivências.
}

A FRELIMO, ao assumir o poder, como já afirmamos anteriormente, introduz uma forma de organização social com forte inclinação ideológica marxista-leninista, baseada no desejoda eliminação dos "vestígios" do capitalismo colonial português no país, visando à formação de uma sociedade nova. A sua implementação afetou, fortemente, os interesses tradicionais e as identidades culturais, as práticas religiosas institucionalizadas, as células familiares, os poderes e as leis locais, os códigos de conduta, a gastronomia, a saúde, a morte, as redes da sociabilidade e solidariedade, as normas de casamentos comunitários, entre vários.

Em suma, o processo de construção da identidade e da nacionalidade no período pós-independência baseou-se na mobilização do povo, na comunhão da experiência da dominação colonial, na crença ao futuro melhor alicerçado ao marxismo-leninismo, no uso do português como língua de unidade, na instrução como meio para o povo tomar o poder. Com base nesses pressupostos, José (2008, p. 154) acrescenta:

[...] a construção da identidade nacional após independência passou pela recriação de símbolos nacionais, também através de condecorações de (cidadãos exemplares) para o processo revolucionário. Esse ritual, como aconteceu no período colonial, teve importância extrema para a legitimação do Estado e consequente adesão dos cidadãos aos seus comandos políticos. O Estado criou novos heróis e símbolos, substituindo-os por alguns dos velhos, assim como se apropriou de outros que outrora serviram os propósitos coloniais. 
As mudanças operadas pela FRELIMO geraram desconfianças internas e externas, levando o país a uma guerra civil de 16 anos que, segundo se afirma, para além de matar cerca de um milhão de pessoas e enormes destruições, modificou a noção do que seria a nação sonhada, especialmente a ressignificação da identidade e nacionalidade moçambicanas que, na literatura, inicia-se durante a guerra, com a geração Charrua e se acentua com assinatura do Acordo Geral de Paz; é alterada a Constituição da República que prevê o respeito pela pluralidade, o reconhecimento da diferença cultural e linguística, a valorização da produção, difusão e consumo da literatura oral e popular.

Com base no exposto, colocamos a seguinte questão: Como a literatura moçambicana representa a ressignificação da identidade e da nacionalidade? Tomando o pensamento de Basto (2008, p. 91) que observa as discussões em torno da literatura, identidade e institucionalização a partir dos princípios da década de 1980 citamos:

\footnotetext{
Entre o caso do concurso literário em 1980/81 e a revista Charrua realizou-se, em Agosto de 1982, em Maputo, a conferência constitutiva da Associação dos Escritores Moçambicanos - AEMO. O seu aparecimento vai conferir peso a questões que concernem uma institucionalização da literatura, mas também às que evocam problemáticas identitárias (o que por «moçambicana» se delimita e entende). No primeiro caso, a par de uma maior visibilidade do escritor e do seu trabalho, resultam duas consequências: o estatuto social que lhe será associado e a arbitragem da produção literária "que instâncias têm a legitimidade para o fazer?". Podemos vê-las nos debates «literatura jovem/jovem literatura»e o "assalto à instituição literária". No segundo caso trará nova visibilidade às discussões sobre "quem é escritor moçambicano?”, “quando e com quem começa a literatura moçambicana?”, o que define uma “escrita moçambicana?”, (língua? tema? personagem? estilo? género?) e quem está legitimado, racial e socialmente para o fazer. As polémicas geradas em torno do livro de Mia Couto Vozes anoitecidas, mas também de Malungate de Albino Magaia, são bons exemplos. São questões importantes, algumas ainda hoje não resolvidas, mesmo se a progressiva autonomia dos escritores do ponto de vista editorial abafe as perguntas pendentes.
}

Nessa altura, a situação do país coloca os escritores numa posição estratégica para abarcar todos os conflitos que caracterizam a sociedade. Olhando para a implantação da ideologia marxista-leninista e a situação da guerra perante o silêncio social diante da população marginalizada, aos gritos de desespero e resistência, alguns escritores procuraram emprestar o seu clamor crítico. Assim, a literatura serve como um dos registos da memória dos acontecimentos numa missão de proposta catártica à sociedade moçambicana. Entre os vários escritores e obras, destacamos: Terra Sonâmbula (1992) e A Varanda do Frangipani (1996), de Mia Couto; Ventos do Apocalipse (1996), de Paulina Chiziane. A escolha dessas obras representativas deveu-se ao fato de as mesmas serem consideradas como obras da "guerra", por narrarem a história dos acontecimentos da guerra civil e as suas 
consequências, tentando emitir, ao mesmo tempo, mensagens de alento ao povo apesar da identidade politizada que o país aspirava.

Para entendermos melhor a importância da literatura na construção da identidade e da nacionalidade, pretendemos percorrer este caminho avaliando as condições e os fatos peculiares do contexto sociohistórico em que as obras de Mia Couto e Paulina Chiziane são produzidas, tal como Campos (2010, pp. 7-8) sustenta:

\footnotetext{
O texto literário desempenha uma função social e histórica à medida que se constitui em um importante meio de denúncia, de registo, de diálogo, construções, desconstruções e expressão. Em seu permeável de ideias a literatura adquire legitimidade e importância como forma de reflexão. Torna-se um representativo instrumento de manifestação das ideias, sentimentos, dores, anseios e desejos humanos. Nesse pressuposto, pode-se dizer que o texto literário, muitas vezes, serve de instrumento para relatar a realidade, com intuito de fazer pensar, persuadir, informar, documentar, alertar, refletir ou simplesmente proporcionar prazer ao leitor; e serve também como condutor de conhecimento do mundo cuja práxis sociais permitem a conscientização de realidades passadas, presentes e projeções futuras.
}

A passagem pretende sustentar que o texto literário é um instrumento onde o escritor recria as coisas da realidade para que estejam ao alcance de todos. Nesse caso, o trecho ora citado ilustra a possibilidade de apreensão e transformação da realidade pelo escritor, numa articulação entre a ideologia e a cultura.

A partir desse raciocínio, podemos afirmar que a cultura moçambicana, a partir do período pós-independência está matizada de um passado colonial recente (cultura ocidental), dos efeitos das guerras de libertação e civil (ideologia marxista leninista/poesia de combate), assim como a valorização da pluralidade. É com base nessas cores que está pintado o contexto moçambicano sugerindo, como afirma Bhabha (1998, pp. 20-1) "ambivalente de entre-lugares" em que a sociedade moçambicana se revela. Portanto, podemos aferir que é, na verdade, nesse contexto em que Mia Couto e Paulina Chiziane escrevem suas narrativas.

Em outras palavras, a leitura de Bhabha entendemos que este autor atesta que as culturas são dinâmicas e têm uma caraterística híbrida porque vivem em constante negociação em vários níveis de troca; são mulatas, anfíbias, intervalares, mutáveis, impuras e inovadoras. Por isso, este raciocínio nos remete para as teorias e críticas pós-coloniais reveladoras da complexidade fronteiriça entre políticas culturais, desconstruindo a relação binária que opõe entre cultura do centro e da periferia.

A partir da década de 1990 os debates e discursos sobre a construção da Nação moçambicana, a identidade e a nacionalidade são redimensionados subvertendo, assim, os discursos das décadas de 1970 e 1980, marcados pela ideologia marxista-leninista da FRELIMO, cujo líder, Samora Moisés Machel, defendia a utopia 
da eliminação das comunidades: makonde, makhuwa, lomwé, kimwani, nahara, yão, masena, ndau, xitswa, tewe, nyungwe, chuwabu, xangana, cope, tsonga, ronga, nguni, entre várias -, para o surgimento da Nação, através da fusão de todas as comunidades numa só: a moçambicana.

O discurso oficial do presidente Samora e outros membros do governo, nos comícios populares, escutava-se: Viva a FRELIMO! Abaixo o tribalismo! Abaixo o regionalismo! Abaixo a feitiçaria e o curandeirismo! Viva a unidade nacional! A população respondia, em voz alta, erguendo o braço direito: Viva! Baixando o braço direito: abaixo!

A obra Terra Sonâmbula, de Mia Couto, revela o acirramento da guerra e seus malefícios sobretudo na desestruturação da população rural que vivia escondida nas matas, refugiada ou deslocada dentro e fora do país. Havia banalização da morte porque era semeada em todos os lados, às vezes praticada por crianças-soldado; havia corpos abandonados nas estradas, nas matas e entre os escombros dos edifícios bombardeados por aviões de guerra; homens assassinados a baionetas a sangue frio ou "regados" com armas ou atingidos pelos canhões ou carbonizadas e "grelhados" nos carros incendiados. Muitos supostos colaboradores com o inimigo foram capturados e assassinados em sessões públicas nas cidades como sinal de desencorajamento e pertencimento ao "inimigo".

Muitos jovens, crianças e adolescentes foram recrutados pelas partes em conflito (o governo da FRELIMO e a RENAMO) como soldados em nome da "defesa do povo moçambicano". Nessa fase, em Moçambique era tudo monótono, o luto, a pobreza, a fome, o desespero, as estradas desertas, as paisagens e o brilho natural do clima votado ao esquecimentos caraterizama o momento. Apesar disso, a narrativa de Mia (1992, p. 6) aponta, em alguns momentos, sinais de esperança:

\footnotetext{
Naquele lugar, a guerra tinha morto a estrada. Pelos caminhos só as hienas se arrastavam, focinhando entre cinzas e poeiras. A paisagem se mestiçara de tristezas nunca vistas, em cores que se pegavam à boca. Eram cores sujas, tão sujas que tinham perdido toda a leveza, esquecidas da ousadia de levantar asas pelo azul. Aqui, o céu se tornara impossível. E os viventes se acostumaram ao chão, em resignada aprendizagem da morte. A estrada que agora se abre a nossos olhos não se entrecruza com outra nenhuma. Está mais deitada que os séculos, suportando sozinha toda a distância. Pelas bermas apodrecem carros incendiados, restos de pilhagens. Na savana em volta, apenas os embondeiros contemplam o mundo a desflorir.
}

Como uma das causas do acirramento da prolongada guerra resulta da recusa da hegemonia e do projeto da ideologia do partido FRELIMO, a obra reveste-se de nuances da denúncia e repúdio aos desmandos da mesma.

Couto (1992, pp. 6-8) no caso do presente romance, no diálogo entre o velho Tuhair e o jovem Muidinga, delineia o encontro permanente entre o velho e o novo, a escrita e a oralidade, a ancestralidade, a tradição e a modernidade. 
[...] o velho teve que lhe ensinar todos os inícios: andar, falar, pensar [...]. O miúdo lê em voz alta. Seus olhos se abrem mais uma vez, lenta e cuidadosa, vai decifrando as letras. Ler era uma coisa que ele apenas agora se recorda saber. $\mathrm{O}$ velho Tuhair ignorante das letras, não lhe despertava a faculdade de leitura.

Por seu turno, a obra A Varanda do Frangipani, Couto (1996, pp. 70-1) apresenta um alerta sobre o desaparecimento gradual da tradição causada pelas interdições, política assimilacionista colonial, guerras prolongadas, organizações e confissões religiosas "estranhas" neopentecostais (de origem brasileira, europeia e norte americana) por defenderem o monoteísmo e a naturalidade na morte dos mais velhos. Vejamos na passagem a conversa entre a enfermeira Marta Gimo e o inspetor Idizinena fortaleza:

O culpado que você procura, caro Idizine, não é uma pessoa. É a guerra. Todas as culpas são da guerra. Foi ela que matou Vasto. Foi ela que rasgou o mundo onde gente idosa tinha brilho e cabimento. Estes velhos que aqui apodrecem, antes do conflito eram amados. Havia um mundo que os recebia, as famílias se arrumavam para os idosos. Depois a violência trouxe outras razões. E os velhos foram expulsos do mundo, expulsos de nós mesmos [...] ao menos aqui na fortaleza os velhos intentavam outra ordem na minha vivência. Eles me davam o ciclo dos sonhos. Seus pequenos delírios eram os novos muros da minha fortaleza. Deve compreender: eu fui educada como uma assimilada. Sou de Inhambane, minhas famílias já há muito perderam seus nomes africanos.

Do mesmo modo, sobre a possibilidade de contribuição da literatura e da escrita coutiana no processo de construção da identidade José (2008, pp. 150-1) afirma:

A literatura e, particularmente, a obra de Mia Couto, evidencia-se pela forma inventiva com que capta a riqueza destas dinâmicas. Não se bastando com a mera intermediação de sentidos, Mia Couto afirma-se como um interlocutor importante no processo de construção na identidade nacional, tanto porque, contra a tendência da homogeneização das experiências, põe em diálogo e em confronto os diversos elementos identitários em presença, como também porque projeta, para o país e para o mundo, uma ideia de moçambicanidade e de cidadania. Longe de (re)criar identidades essencialistas, cristalizadas no tempo e no espaço, Mia Couto é fiel à historicidade, complexidade e dinâmica que lhes são próprias.

Por seu turno, na mesma linha da escrita coutiana, Chiziane (1996, p. 195) numa passagem da obra Ventos do Apocalipse, reflete sobre a necessidade do respeito e preservação das práticas presentes na tradição buscando ressaltar aquilo que a sua criação ficcional testemunha a ideia da identidade moçambicana:

Minha gente! Falar dos defuntos é falar dos corpos mortos, das caveiras, dos ossos, da cinza e pó. Falar dos antepassados é falar da história desse povo, da tradição e não do fanatismo cego, desmedido. Não há novo sem velho. O velho lega a herança ao novo. O novo em sua origem no velho. Ninguém pode 
olhar para a posterioridade sem olhar para o passado, para a história. A vida é uma linha contínua que se prolonga por gerações e gerações. Aquele que respeita a morte também respeita a vida. Acreditar nos antepassados é acreditar na continuidade e na imortalidade do homem.

Na mesma obra Chiziane (1996, p. 97) olha para o fenómeno da guerra e seus efeitos sobre a cultura ao afirmar:

\begin{abstract}
Mataram os velhos, mataram os novos. O povo não tem bibliotecas e nem escreve. A sua história, os seus segredos residem na massa cinzenta dos antigos, cada cabeça é um capítulo, um livro, uma enciclopédia, uma biblioteca. As cabeças foram decepadas e em breve será o enterro.
\end{abstract}

As passagens transcritas refletem o projeto na Nação em construção trazendo uma forte carga de denúncia e apelo sobre os velhos silenciados, crianças e jovens desmemoriados porque antes da guerra os velhos eram responsáveis pela educação tradicional. Portanto, com a morte dos sábios nota-se uma tensão entre os valores e crenças tradicionais pondo em causa a educação das futuras gerações a fim de darem a continuidade da tradição.

Por seu turno, a escrita de Chiziane, denuncia os efeitos da guerra sobre os homens, mulheres, velhos, crianças, jovens, aldeias, lugares, famílias, amigos, memórias e histórias, refletindo, ao mesmo tempo, as múltiplas e complexas realidades em Moçambique. Chiziane (1996, p.150) defende: "Os culpados são todos. $\mathrm{O}$ culpado não é ninguém. A culpa é a imperfeição da natureza humana. $\mathrm{O}$ homem ama a sua própria vida mas, desde o princípio do mundo se diverte em tirar as vidas alheias".

Por um lado, a guerra é representada como extensão da maldade humana através da universalização dos problemas de Moçambique e, por outro, o narrador pretende fazer um balanço da Nação no espaço e tempo buscando representar a vitória do bem sobre o mal, propagando mensagens de esperança para um futuro risonho aos moçambicanos. Como forma de dar mais alento, Chiziane (1996, p.195) enfatiza: "É verdade que muito se perdeu, mas nós ainda existimos. Deve-se procurar melhorar a vida tendo como base o que há de bom na nossa cultura".

As obras de Mia e Chiziane que discutimos, podem-nos remeter para as razões da escrita literária, a segui refletidas por Junior (1953, pp. 5-6):

Escrever representa sempre uma intenção e é, ao mesmo tempo, uma necessidade. Necessidade é uma exigência forte que traz expressa uma ânsia de comunicação espiritual. O homem também sofre fomes desesperados de espírito, e essa de comunicação é imperativa nele, domina-o totalmente, aquele homem que vai abrindo os olhos para a vida e se torna mais compreensivo à medida que lhe explicam o que a própria vida contém de verdadeiramente belo, de extraordinariamente humano. Para escrever é necessário ter vivido o que se escreve, ter passado estados de emoção, de deslumbramentos de alma, 
entusiasmos que ficaram em nós e foram momentos de exaltação, gozo que há-de arder sempre e não chegará, jamais, a ser cinza morta. Será chama perpétua, labaredas alta. Vive-se a dor, o sofrimento que depura e engrandece a criatura humana e torna gigante quando se escreve. Vive-se o nosso drama e o drama do próximo. Vive-se o meio ambiente, a sua cor, o seu movimento. Os tipos humanos que nele se agitam, são também elementos que o artista encontra nas suas caminhadas à procura de material vivo para a sua obra.

A passagem remete-nos à observação de que as obras apresentadas tivessem sido produzidas voltadas pelo fato de a formação da nacionalidade moçambicana ter sido adiada por duas causas essenciais: a colonização portuguesa, que impediu a criação de instituições de ensino de forma que existisse a organização de campos intelectuais no país; e a ideologia marxista-leninista que fundamenta a formação do Homem Novo e de uma nação nova, aliada à eclosão da guerra civil e o seu impacto. Portanto, é nesse viés que as narrativas de Couto e Chiziane captam o conceito de Nação por outros caminhos, apresentando-se como propostas da construção da identidade paralela à visão utópica da FRELIMO. Desse modo, ao recriar o real, a literatura propõe a construção de uma identidade para o país resgatando e exaltando a tradição, apontando para um Moçambique que se tem e não um Moçambique que se pretende inventar politicamente.

Retomando, o tópico dessa reflexão, "A literatura moçambicana: caminhos da consolidação", tem ancoragem nessa discussão se lançarmos um olhar pela forma como trilha nos períodos antes, durante e depois da colonização. Matusse (2015), no prefácio da obra Literatura Moçambicana: da ameaça ao esquecimento à urgência do Resgate (2015), recua para os anos sessenta do século passado para mostrar que os debates acerca da literatura moçambicana, na metrópole, versavam sobre a possibilidade ou não da sua existência enquanto sistema autônomo da língua portuguesa. As vozes sonantes só viriam a se abrandar com o advento da independência e da formação da Nação que legitima a autonomia da literatura moçambicana, mas ao mesmo tempo reivindicam a inclusão dos autores externos, com direito à cidadania literária moçambicana, que os internos contestam. Acrescenta, na sua abordagem que foi sob égide das Literaturas Africanas de Língua Portuguesa que a literatura moçambicana passa a ser estudada como disciplina em universidades externas e não internas.

Certamente, Matusse, prossegue, dizendo nesta paráfrase que foi no exterior onde se criaram as condições para a escrita de uma História da Literatura Moçambicana e outros aspetos relevantes. Mais ainda, a concepção endógena sobre as matérias de ensino da literatura no sistema escolar está cada vez mais derrapando e dando lugar ao foco externo. A isso está aliada a incipiência da crítica literária interna para cumprir a divulgação ampla das obras e autores moçambicanos. E, 
por último, muitas vezes, as obras são editadas no estrangeiro ou por filiais das editoras estrangeiras situadas no país e só mais tarde é que chegam ao país para fins de divulgação e consumo. Até ao momento, Moçambique possui maior número de editoras filiais e não 100\% moçambicanas que nem sempre põem em circulação, divulgação e consumo das obras para os leitores moçambicanos e a respetiva legitimação, configurando-se o que Candido (1999, p. 98) afirma: "Enquanto sistema, não atingiu uma maturidade cultural plena". Por essas razões, os dados mostram que a Literatura Moçambicana se projeta numa ótica exógena em relação à endógena.

\section{Considerações finais}

Os caminhos pelos quais a literatura moçambicana tem trilhado podem ter a ver com as várias formas de construção da própria Nação. O fato de esse processo de construção ser recente, prevalecem até aos nossos dias preconceitos do tempo colonial e do marxista leninista entre os moçambicanos e as suas instituições.

Outrossim, com base nesse desiderato, uma Nação jovem de dimensões vastas como Moçambique precisa esperar durante longo tempo para que o sistema literário e cultural iniciado nos finais do século XVIII faça coincidir a sua configuração com as suas fronteiras e limites geográficos. Falando com mais rigor, podemos afirmar que nem hoje, em pleno século XXI, apesar dos diversos meios de comunicação, também literários (a mídia, rádio, cinema, televisão, celular, internet, disco), podemos diagnosticar semelhante ajustamento. Portanto, reiteradamente, a literatura moçambicana está caminhando para a sua consolidação, enquanto sistema.

\section{Referências}

Basto, M-B. (2008). Relendo a Literatura Moçambicana dos Anos 80. In: Ribeiro, M. C. e Meneses, M. P. (Orgs.). Moçambique: das Palavras escritas [pp.77-110]. Porto: Edições Afrontamento.

Bhahba, H. K. (1998). O Local da Cultura. Trad. Myriam Ávila; Eliana Lourenço de Lima Reis e Cláudia Renate Gonçalves. Belo Horizonte: Editora UFMG.

Cabaço, J. L. (2009). Moçambique: identidade, Colonialismo e libertação. São Paulo: Editora UNESP.

Campos, J. S. (2010). A Reconfiguração da identidade moçambicana representada nos romances de Mia Couto. Disponível em: http://www.africaeafricanidades.com.br/documentos/01112010_07.pdf.

Candido, A. (1999).Iniciação à Literatura Brasileira:Resumo para principiantes. (3a . ed.), São Paulo: Humanitas Publicações.

Chaves, R. (2003). Angola e Moçambique nos anos 60: A periferia no centro do território poético. In: Chaves, R. \& Macêdo, T. (Orgs.). Literaturas em Movimento: hibridismo cultural e exercício crítico. [pp. 210-223]. São Paulo: Arte \& Ciência. 
Chiziane, P. (1996). Ventos do Apocalipse. Lisboa: Caminho.

Couto, M. (1992). Terra Sonâmbula. Lisboa: Editorial Caminho. (1996). A Varanda do Frangipani. Lisboa: Editorial Caminho.

José, A. C. (2008). Revolução e identidades Nacionais em Moçambique: diálogos (in)confessados. In: Ribeiro, M. C. \& Meneses, M. P. (Orgs.). Moçambique: das palavras escritas. [pp.141159]. Porto: Edições Afrontamento.

Júnior, R. (1953). Literatura colonial: ensaios. Lourenço Marques: Travessa do Noronha.

Leite, A. M. (2013). Oralidades e Escritas nas literaturas africanas. Lisboa: Edições Colibri. .(2008). Tópicos para uma História da Literatura Moçambicana.

Ribeiro, M. C. \& Meneses, M. P. (Orgs.). Moçambique: das palavras escritas. [pp. 47-75]. Porto: Edições Afrontamento.

Matusse, G. (2015). Literatura Moçambicana: da ameaça ao esquecimento à urgência do Resgate. Maputo: Alcance Editores.

Mendes, O. (1980). Sobre Literatura Moçambicana. Maputo: Instituto Nacional do Livro e do Disco.

Mendonça, F. (2011).Literatura Moçambicana: as dobras da escrita. Maputo: Ndjira, Coleção Horizonte da Palavra.

Noa, F. (1999). Literatura Colonial em Moçambique: o paradigma submerso.[pp.58-69]. Viatlântica, n.3. São Paulo, USP. Disponível em: http://edisciplinas.usp.br. $>$ pluginfie $>$ php $>\bmod$ resource $>$ content $>$ pdf.

(2008). Literatura Moçambicana: Os Trilhos e as Margens. In Ribeiro, M. C. \& Meneses, M. P. (Orgs.). Moçambique: das Palavras escritas. [pp.35-45]. Porto: Edições Afrontamento.

Newitt, M. (1995). História de Moçambique. Trad. Lucília Rodrigues e Maria Georgina Segurado. Portugal: Publicações Europa América.

Secco, C. L. T. R. (1999). O Mar nas Letras Moçambicanas: As conotações do mar na poética moçambicana. In: Secco, C. L. T. R. (Org.). Antologia do Mar na Poesia Africana de Língua Portuguesa do Século XX: Moçambique, São Tomé e Príncipe e Guiné-Bissau.[pp.10-43]. Cadernos de Letras Africanas 3. V.III, Faculdade de Letras: UFRJ.

Sousa, I. S. (2014). Fiç̧ão do Outro: império, raça e subjetividade no Moçambique colonial. CLEPU. Disponível em: www.Lusosofia.net/textos.

Williams, F. G. (2005). Poets of Mozambique, a bilingualSelection: poetas de Moçambique, uma seleção bilingue. Portugal, Lisboa, Instituto Camões. Disponível em: www.parkinfamily.org/ typography/book/Mozambique\%20poetry.pdf. 